\title{
A panel of tumor markers, calreticulin, annexin $A 2$, and annexin $A 3$ in upper tract urothelial carcinoma identified by proteomic and immunological analysis
}

Chih-Ming Lu ${ }^{1 \dagger}$, Jen-Jie Lin ${ }^{2 \dagger}$, Han-Hsiang Huang ${ }^{3}$, Ying-Chin Ko ${ }^{4}$, Jue-Liang Hsu', Jiing-Chuan Chen ${ }^{6}$, Zhong-Hao $\mathrm{Din}^{7}$ and Yu-Jen $\mathrm{Wu}^{3^{*}}$

\begin{abstract}
Background: Upper tract urothelial carcinoma (UTUC) is a tumor with sizable metastases and local recurrence. It has a worse prognosis than bladder cancer. This study was designed to investigate the urinary potential tumor markers of UTUC.

Methods: Between January 2008 and January 2009, urine was sampled from 13 patients with UTUC and 20 healthy adults. The current study identified biomarkers for UTUC using non-fixed volume stepwise weak anion exchange chromatography for fractionation of urine protein prior to two-dimensional gel electrophoresis.

Results: Fifty five differential proteins have been determined by comparing with the 2-DE maps of the urine of UTUC patients and those of healthy people. Western blotting analysis and immunohistochemistry of tumor tissues and normal tissues from patients with UTUC were carried out to further verify five possible UTUC biomarkers, including zinc-alpha-2-glycoprotein, calreticulin, annexin A2, annexin A3 and haptoglobin. The data of western blot and immunohistochemical analysis are consistent with the 2-DE data. Combined the experimental data in the urine and in tumor tissues collected from patients with UTUC, the crucial over-expressed proteins are calreticulin, annexin $\mathrm{A} 2$, and annexin $\mathrm{A} 3$.
\end{abstract}

Conclusions: Calreticulin, annexin A2, and annexin A3 are very likely a panel of biomarkers with potential value for UTUC diagnosis.

Keywords: Upper tract urothelial carcinoma, Proteomic, Urine, Annexin A2, Annexin A3, Calreticulin, Zn-alpha-2glycoprotein

\section{Background}

Urothelial (transitional cell) carcinoma is the most common malignancy in epithelium of the bladder, ureter, and kidney. Upper tract urothelial carcinoma (UTUC) is relative rare and accounting for $5 \%$ of all urothelial neoplasms. Three quarters of the UTUC incidence occur in renal pelvis. The overall incidence rate of UTUC in Taiwan is higher than that in worldwide else [1]. Investigation suggested this is due to a wide usage of herb drug

\footnotetext{
* Correspondence: wyr924@ms24.hinet.net

${ }^{\dagger}$ Equal contributors

${ }^{3}$ Department of Beauty Science, Meiho University, Pingtung, Taiwan

Full list of author information is available at the end of the article
}

such as Aristolochia manshuriensis Kom and analgesics in Taiwan. Bladder cancer rarely migrates to upper tract. Patients with UTUC have a higher risk of developing bladder cancers (30-50\%) [2]. In contrast to the application of transurethral resection and intravesical chemotherapy to avoid cystectomy in life time for early stage bladder cancer, UTUC mostly undergo radical nephroureterectomy with the risk of hemodialysis. Oftentimes UTUC has a poorer prognosis than bladder cancer $[3,4]$. Reports regarding medically useful tumor markers for UTUC are very limited. The common manifestations of urothelial carcinomas are gross hematuria. Most of the urological diseases, such as urinary tract infection, benign

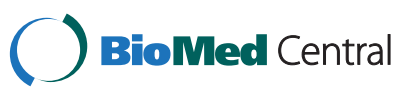

(c) 2014 Lu et al.; licensee BioMed Central Ltd. This is an Open Access article distributed under the terms of the Creative Commons Attribution License (http://creativecommons.org/licenses/by/2.0), which permits unrestricted use, distribution, and reproduction in any medium, provided the original work is properly credited. The Creative Commons Public Domain Dedication waiver (http://creativecommons.org/publicdomain/zero/1.0/) applies to the data made available in this article unless otherwise stated. 
prostatic hyperplasia, and urinary calculi may also show hematuria. The available diagnostic methods for UTUC are urine cytology, CT urography, and cystoscopy. However, the sensitivity and specificity of these manners are not satisfactory.

Proteomic analysis of tissues or body fluids has been applied in clinical detections. Identification of disease biomarkers is potentially useful for diagnosis, monitoring disease progress as well as evaluation of therapies. Twodimensional gel electrophoresis (2-DE) is an essential tool for proteome studies. It has been used in biomarker identification for diagnosis and clinical monitoring of diseases [5]. Urine contain large amount of high-abundance proteins such as immunoglobulin heavy and light chain proteins, generally obscure low-abundance proteins on 2DE maps. Previously a non-fixed volume stepwise isocratic elution weak anion exchange (WAX) chromatography was used to fractionate healthy urine proteins into four groups prior to performing two dimensional electrophoresis and the results indicated that low-abundance proteins can be detected on 2-DE maps and identified by LC-MS/MS analysis after the removal of high-abundance proteins [6]. Herein our study identifies biomarkers for UTUC using non-fixed volume stepwise WAX chromatography for fractionation of urine protein prior to 2-DE and using comparative proteomic analysis for the detection of differential proteins. The urine proteins of patients with UTUC were fractionated into four fractions following the same procedures for that of healthy people. Differential protein spots were detected by comparing the 2-DE maps of UTUC patients with those of healthy people. The differential protein spots were identified and further evaluated by urine western blotting analysis while tumor tissues collected from UTUC patients were further assessed by immnohistochemistry and western blot to provide potentially important protein markers for UTUC.

\section{Methods}

This protocol was approved by the Institute Review Board of the Buddhist Dalin Tzu Chi Hospital (Approval No. B09601020). We obtained all patients' consent for both the urine collection and the tumor sample collection and use.

\section{Collection of urine of healthy people}

Urine samples were collected from 20 healthy individuals including eleven males and nine females, aged between 18 and 54 years, who had neither history of drug administration nor renal disorders during sample collection period. All females had no menstruation at the time of sample collection. A $100 \mathrm{ml}$ urine sample was collected for every person in the mornings and the samples were combined together. The urine samples were treated with protease inhibitor cocktail to avoid proteolysis.
They were then centrifuged at $12,000 \mathrm{rpm}$ to remove insoluble material and cell debris at $4^{\circ} \mathrm{C}$. Stirred Ultrafiltration Cell 8400 (Millipore, Billerica, MA, USA) and YM5 membrane (5000 molecular weight cut-off) were used to concentrate the solution and remove small interference molecules. The concentrated urine samples had a final volume of $50 \mathrm{ml}$ and were stored at $-80^{\circ} \mathrm{C}$ for future use.

\section{Collection of urine of patients with UTUC}

The incidence of UTUC is relatively rare and it is difficult to have a large number of patients in a local area. A total of 13 patients with UTUC enrolled in this study between January, 2008 and January, 2009. There were 5 male and 8 female. The average age was 62.6 years (3380 years old). All the patients were newly diagnosed and confirmed by histological examination. A $100 \mathrm{ml}$ urine sample was collected for each patient prior to surgery and the samples were combined together. The further treatments of the samples adopted the same procedures for the samples of healthy people.

\section{Collection of tumor tissue of patient with UTUC}

The tissue specimen were harvested by nephroureterectomy for UTUC. In addition, the normal control epithelium was resected from approximately $1 \mathrm{~cm}$ away from the tumor. The tissue was collected at least $5 \mathrm{~mm} \times$ $5 \mathrm{~mm} \times 5 \mathrm{~mm}$ in size. These tissues were immediately stored in liquid nitrogen for later analysis.

\section{Fractionation of urine proteome by non-fixed volume stepwise WAX}

According to the previous procedures [6], a column $(5 \mathrm{~cm} \times 10 \mathrm{~cm})$ packed with 50 gram DEAE-Sephacel (GE Healthcare) which was equilibrated with $50 \mathrm{mM}$ Tris- $\mathrm{HCl}$ buffer for five times before use. Twenty $\mathrm{ml}$ of concentrated urine samples were dialyzed at $4^{\circ} \mathrm{C}$ overnight and then loaded to the column. First the column was eluted by $50 \mathrm{mM}$ Tris- $\mathrm{HCl}$ buffer without salt at a flow rate of $40 \mathrm{ml} / \mathrm{hr}$. The column was eluted until no proteins were detected in the eluent by Bradford dye assay. A total combined eluent was collected and concentrated by Stirred Ultrafiltration Cell 8400 and YM5 membrane to a volume of $50 \mathrm{ml}$. The sample was called fraction unbound. Then, a solution of $50 \mathrm{mM} \mathrm{NaCl} /$ $50 \mathrm{mM}$ Tris- $\mathrm{HCl}$ buffer was used to elute the column until no protein was detected in the eluent and a total solution was collected and concentrated by the same procedure to obtain the fraction $\mathrm{NaCl}-1.100 \mathrm{mM} \mathrm{NaCl} /$ $50 \mathrm{mM}$ Tris- $\mathrm{HCl}$ buffer was collected following the same procedures to obtain fraction NaCl-2. $1 \mathrm{M} \mathrm{NaCl} /$ $50 \mathrm{mM}$ Tris- $\mathrm{HCl}$ buffer was collected for the last elution to obtain fraction $\mathrm{NaCl}-3$. 


\section{Urine proteins precipitation and two-dimensional gel electrophoresis}

The urine protein mixture in the supernatant was precipitated out overnight at $-20^{\circ} \mathrm{C}$ by $100 \mathrm{ml} 10 \% \mathrm{TCA} /$ Acetone solution containing $20 \mathrm{mM}$ DTT [7]. The pellet was rinsed in cold acetone containing $20 \mathrm{mM}$ DTT and dried by SpeedVac, then resuspended in a rehydration buffer (8 M urea, 0.5\% CHAPS, 0.5\% IPG buffer, $20 \mathrm{mM}$ DTT, $0.002 \%$ bromophenol blue) at $4{ }^{\circ} \mathrm{C}$ overnight. The protein contents were determined using 2-D Quant Kit (GE Healthcare).

The first dimension electrophoresis (isoelectric focusing) was performed GE Healthcare Ettan IPGphor 3 using the reported procedure [8]. Urine proteins $(50 \mu \mathrm{g})$ were loaded on $11-\mathrm{cm}$ strip. Every $11-\mathrm{cm}$ IPG strip ( $p I$ 4-7 and $p I$ 3-10NL, Immobiline DryStrip) was rehydrated at $50 \mathrm{~V}$ for $12 \mathrm{~h}$, then focused according to the preset program: $200 \mathrm{~V}(2 \mathrm{~h}), 500 \mathrm{~V}(1 \mathrm{~h}), 1,000 \mathrm{~V}(1 \mathrm{~h})$, $4,000 \mathrm{~V}(2 \mathrm{~h}), 8,000 \mathrm{~V}(3 \mathrm{~h})$, until the total Vh reached 32,060 . Then second dimension electrophoresis was done $15 \%$ SDS-PAGE run at $150 \mathrm{~V}$ for $7 \mathrm{~h}$. The second dimension electrophoresis was used SE 600 Ruby electrophoretic unit (Hoeffer). The 2-DE gels were stained with silver staining and then subjected to image analysis with the PDQuest 2-D software (version 7.1.1). 2-DE images were taken in triplicate for each sample and normalized prior to statistical analysis.

\section{Protein spot identification by LC-MS/MS}

The protein spots of interest were excised, destained and then subjected to tryptic in-gel digestion as described in a previous report [9].

The peptide solution was concentrated for the following LC-MS/MS analysis. After desalting with a Millipore ZIP plate (Millipore), the above peptide mixture was separated by nanoflow reversed phase $\mathrm{C} 18$ chromatography on nano LC using the Agilent NanoLC 1200 System and Agilent Zobax $2.1 \mathrm{~mm} \times 150 \mathrm{~mm} \mathrm{C18}$ column. MS analysis was performed using a AB SCIEX QTRAP ${ }^{\circ}$ 5500Q mass spectrometer (Applied Biosystems, CA, USA). The scan range was from $\mathrm{m} / \mathrm{z} 100$ to 1000 for MS. The raw data was processed into a text file format of WIFF with Analyst 1.5.1. MASCOT was used in searching for protein identification by NCBInr protein database.

\section{Western blot analysis}

Western blot was conducted to verify the regulation of 5 differential 2-DE-detected proteins. The protein samples under reducing conditions were loading $20 \mu \mathrm{g}$ total proteins and separated by $12.5 \%$ SDS-PAGE. The proteins on the gel were then transferred to PVDF membranes. The membranes were incubated with rabbit antibodies against human calreticulin (CALR), annexin A2, annexin
A3, haptoglobin (Hp), and zn-alpha-2-glycoprotein (ZAG) at $4^{\circ} \mathrm{C}$ for $2 \mathrm{~h}$ or overnight. The membranes were washed three times in PBST $\left(10 \mathrm{mM} \mathrm{NaH} \mathrm{PO}_{4}, 130 \mathrm{mM} \mathrm{NaCl}\right.$, $0.05 \%$ Tween 20), then incubated with the second antibodies (goat anti-rabbit with horseradish peroxidase conjugated, 1:5,000 in blocking solution) for $1 \mathrm{~h}$. After washing with PBST for three times, the blots were visualized through chemiluminesence by adding ECL western blotting reagents.

\section{Immunohistochemistry}

Using the Bond-Max autostainer (Leica Microsystems), slides were stained with annexin A2 polyclonal antibodies (1:50; ProteinTech Group, Chicago, IL, USA) applied at room temperature for $1 \mathrm{~h}$. Briefly, formalin-fixed and paraffin-embedded tissue array specimens were in Tris- $\mathrm{HCl}$ buffer $(50 \mathrm{mM}$ Tris, $130 \mathrm{mM} \mathrm{NaCl}, 0.05 \%$ Tween 20), rehydrated through serial dilutions of alcohol, and washed in PBST. Slides were stained with previously mentioned antibodies was performed on the fully automated Bond-Max system using onboard heat induced antigen retrieval and a Leica Refine polymer detection system (Leica Microsystems). Diaminobenzidine was used as the chromogen (Leica Microsystems) in all these immunostainings. Negative controls were obtained by excluding the primary antibody. Appropriate positive controls were used throughout the study. These slides were mounted with gum for examination and the images were captured by the Olympus BX51 microscopic/DP71 Digital Camera System (Ina-shi, Nagano, Japan) for study comparison.

\section{Results}

The characteristics of UTUC patients and controls

There were eight males and five females in the UTUC group while eleven males and nine females are in the healthy control group. The mean ages of UTUC patients and healthy controls were 62.6 years (range $33-80$ years) and 34.2 years (range 18-54 years), respectively. In the UTUC group, there were $8(61.5 \%)$ patients with stage pT1/T2, 5 (38.5\%) with stage pT3. Among these UTUC patients, $23.1 \%(3 / 13)$ had grade 3 tumors. Most of the patients had solitary tumors (69.3\%) and big lesions (76.9\% with $>4 \mathrm{~cm}$ in diameter). However, only $66.7 \%$ (6/9) patients showed carcinoma cell in urine cytology (Table 1).

\section{2-DE maps of urine proteome of healthy people and UTUC patients}

A $100 \mathrm{ml}$ urine sample was collected from each of 20 healthy people and 13 UTUC patients. In order to eliminate the individual difference, the samples were combined together. The proteins were precipitated by $10 \%$ TCA/Acetone after dialysis. An equal amount of $50 \mathrm{~g}$ 
Table 1 The characteristics of UTUC patients and controls

\begin{tabular}{|c|c|c|}
\hline & UTUC & Control \\
\hline & $N=13$ & $N=20$ \\
\hline \multicolumn{3}{|l|}{ Sex } \\
\hline Male & $8(61.5 \%)$ & $11(55.0 \%)$ \\
\hline Female & $5(38.5 \%)$ & $9(45.0 \%)$ \\
\hline Mean age (years) & $62.6(33-80)$ & $34.2(18-54)$ \\
\hline \multicolumn{3}{|l|}{ Tumor grade } \\
\hline G1 & 7 (53.8\%) & - \\
\hline G2 & $3(23.1 \%)$ & - \\
\hline G3 & $3(23.1 \%)$ & \\
\hline \multicolumn{3}{|l|}{ T Stage } \\
\hline $\mathrm{T} 1$ & $4(30.7 \%)$ & - \\
\hline $\mathrm{T} 2$ & $4(30.7 \%)$ & - \\
\hline T3 & $5(38.5 \%)$ & - \\
\hline \multicolumn{3}{|l|}{ Urine cytology } \\
\hline Positive & $6(46.2 \%)$ & - \\
\hline Negative & $3(23.1 \%)$ & - \\
\hline Unknown & $4(30.7 \%)$ & - \\
\hline \multicolumn{3}{|l|}{ Tumor size } \\
\hline$<1 \mathrm{~cm}$ & $0(0 \%)$ & - \\
\hline $1-4 \mathrm{~cm}$ & $3(23.1 \%)$ & - \\
\hline$>4 \mathrm{~cm}$ & $10(76.9 \%)$ & - \\
\hline \multicolumn{3}{|l|}{ Tumor multiplicity } \\
\hline Solitary & $9(69.3 \%)$ & - \\
\hline Multiple & $4(30.7 \%)$ & - \\
\hline
\end{tabular}

per gel was resolved in 2-DE using IPG strip ( $p I 4-7$ and pI 3-10NL). The protein spots were visualized with silver stain. The differential proteins in the urine proteome of UTUC patients were examined by comparing with those of healthy people (Figure 1).

\section{Volume stepwise WAX with $\mathrm{NaCl}$ solutions}

A direct 2-DE analysis of a complex protein sample would encounter resolution problem. Usually not all proteins can be identified on a 2-DE map. In order to identify the differential proteins in the urine proteome of patients with UTUC in comparison with that of healthy people, the urine proteome of patients with UTUC was also fractionated into four fractions using the same experimental procedures and conditions. The 2-DE maps of the four fractions of patient with UTUC were shown in Figure 2 (2A for the fraction Unbound, $2 \mathrm{~B}$ for the fraction $\mathrm{NaCl}-1$, $2 \mathrm{C}$ for the fraction $\mathrm{NaCl}-2$, and 2-DE for the fraction $\mathrm{NaCl}-3$; 2A-2D for UTUC patient, 2E-2H for healthy people). The Figure 3A-3F showed the corresponding 2-DE maps of the four fractions of urine proteome of
UTUC patients and healthy people run on $p I$ 3-10 NL. (3A-3D for UTUC patient, 3E-3H for healthy people)

A side-by-side comparison between the 2-DE maps of each fraction of patients and those of healthy people showed clearly different staining patterns. A total of 208 protein spots were detected in Figure 2A comparing with 53 protein spots in Figure 2E, a total of 369 spots were detected in Figure 2B comparing with 102 protein spots in Figure 2F, a total of 350 spots were detected in Figure 2C comparing with 143 protein spots for Figure 2G, and a total of 101 spots were detected in Figure $2 \mathrm{D}$ comparing with 31 protein spots in Figure $2 \mathrm{H}$ by comparative analysis using PDQuest 2-D software (version 7.1.1). A total of 1028 protein spots were shown in Figure 2A-2D comparing with a total of 329 protein spots in Figure 2E-2H.

Analysis of all the differential protein spots would encounter practical difficulties. Identification of fifty-five (spot $1 \sim 55$ ) differential protein spots by LC-MS/MS after excision and in-gel digestion was carried out and the identities are represented in Table 2. The differential proteins spots were defined as the proteins only present in patients or showed intensity difference between patients and healthy people using PDQuest 2-D software. The differential proteins include zinc-alpha-2-glycoprotein (ZAG), heparan sulfate proteoglycan (HSPG), alpha1-microglobulin/bikunin precursor, calreticulin (CALR), haptoglobin $(\mathrm{Hp})$, serotransferrin, ATP-binding cassette sub-family A member 9, annexin A2, annexin A3 sorting nexin-14, Serum albumin, spermatogenesis-associated protein 7, DNA replication licensing factor MCM2, proline-serine-threonine phosphatase-interacting protein 1, dermcidin precursor, glial fibrillary acidic protein, syntaxin-binding protein 4 , and transthyretin.

\section{Western blot analysis of urine and tissue}

Western blot analysis of specific urine proteins was performed to verify the 2-DE results. Western blot data of ZAG, CALR, annexin A2, annexin A3 and Hp in the urine of both patients and healthy people are shown in Figure 4. The results indicated that clearly stronger expression of ZAG, CALR, annexin A2, annexin A3 and $\mathrm{Hp}$ in the urine of patients in comparison with the counterparts in the urine of healthy people. This confirmed the 2-DE data of ZAG (spots 23,24), CALR (spot 31), annexin A2 (spot 53), annexin A3 (spot 29) and Hp (spot $32 \sim 36$ ). Side-by-side comparisons of CALR, ZAG, annexin A2, annexin A3 and Hp showed the different expression between tumor tissues and normal tissues. The expression of CALR, annexin A2, and annexin A3 in the tumor tissues was higher than that in the normal tissues. These results are in accordance with the western blot data on the urine samples of UTUC patients as CALR, annexin A2, and annexin A3 are the reasonable 


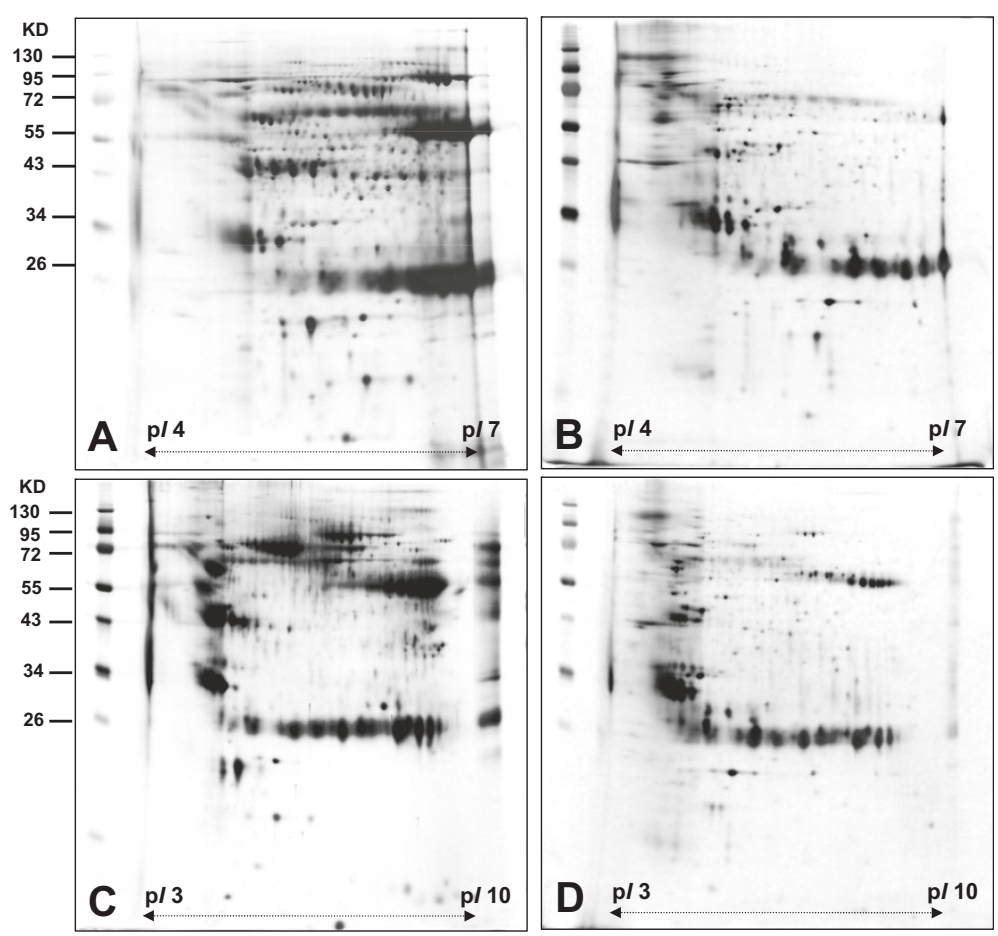

Figure 1 Two-DE maps of urine proteome of UTUC and healthy people. (A)(C) 2-DE maps were for UTUC and (B)(D) for healthy people.

connection between urine proteins of UTUC and the tumor tissues (Figure 5).

\section{Immunoreactivity of annexin A2}

The immunoreactive staining detected by annexin A2 antibodies appeared in layers of UTUC tissue and normal tissue confined to the two proteins in the cytoplasm of the epithelium. The immunoreactive expression of the tumor tissue is stronger than that in normal tissues (Figure 6). The positive staining rate of urothelial carcinoma was $84.6 \%(11 / 13)$, compared to control with $7.7 \%$ (1/13). All 2 UTUCs with negative annexin A2 expression were pT1G1. The only normal urothelium with postive expression was harvested from a patient with pT3G3 (Table 3). The sensitivity and specificity of annexin A2 expression were 50\% (2/4) and 100\% (0/4) for pT1, 100\% (4/4) and 100\% (4/4) for pT2, and 100\% (5/5) and $80 \%(1 / 5)$ for pT3, 71.4\% (5/7) and 100\% (7/7) for G1, $100 \%(3 / 3)$ and $100 \%(3 / 3)$ for G2, and $100 \%(3 / 3)$ and $66.7 \%(2 / 3)$ for G3, respectively (Table 4). Anyway, the study failed to calculate statistical significance due to samll sample size.

\section{Discussion}

The differential proteins in UTUC patients and those in healthy controls were compared using proteomic analysis in this study. The ages of UTUC patients and healthy controls were 62.6 years (range 33-80 years) and
34.2 years (range 18-54 years), respectively. UTUC usually occurs in older patients and elderly people appear high occurrence of progressive diseases such as type 2 diabetes mellitus and osteoarthritis. Moreover, the elderly in Taiwan often have habits of taking medicine, Chinese herbal medicine and nutritional supplements. Hence, it is clinically difficult to find healthy controls of similar age. We consider that certain urine different proteins are attributed to old age. Therefore we design an additive study to compare the proteins of normal and tumor tissues from patients with UTUC. The further study tries to clarify that those different proteins are produced by urothelial tumors rather than normal tissues.

However, non-fixed volume stepwise WAX chromatography is an effective method to fractionate urine protein. Many low-abundance proteins in the urine of UTUC patients were enriched and identified. A total of 1028 differential protein spots have been detected in the four fractions by comparative proteomic analysis. LCMS/MS analysis has determined fifty-five protein spots. We expected some proteins expression were related to age difference. Investigation of the proteins were associated with incidence of cancers, including ZAG, CALR, annexin A2, annexin A3 and Hp [10-14]. Some of the proteins have not been reported yet in UTUC. The 2 -DE data were further confirmed by western blot analysis indicating the over-expression of CALR, annexin A2, and annexin A3 in the urine and tissue of 


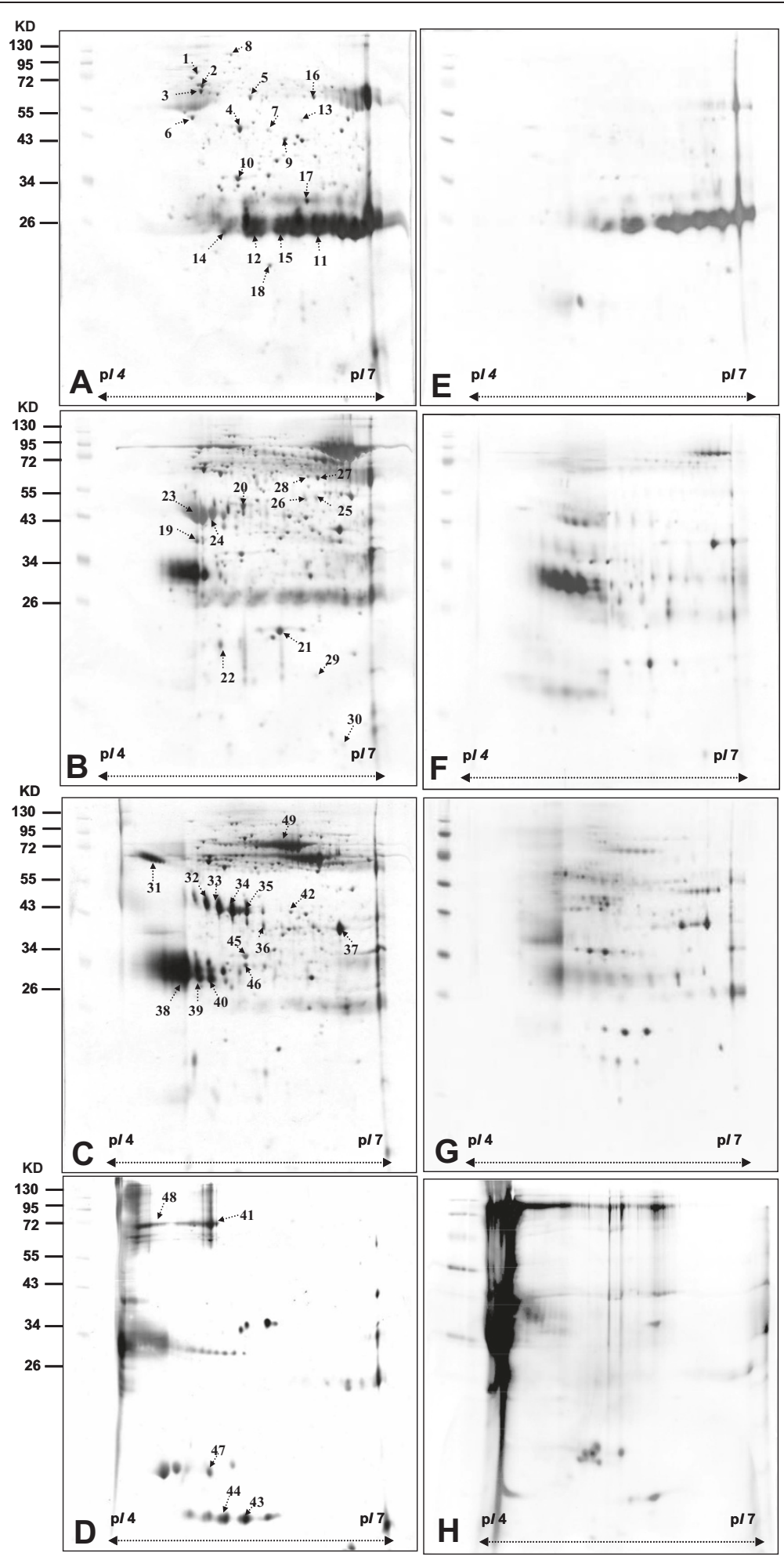

Figure 2 2-DE maps of fractions of urine proteome of UTUC patients and healthy people obtained by non-fixed volume stepwise elution DEAE-Sephacel anion exchange chromatography. ( $p / 4-7)(\mathbf{A}),(\mathbf{E})$ unbound Proteins in fraction (B), (F) Proteins in fraction NaCl-1 obtained by elution with $50 \mathrm{mM} \mathrm{NaCl}$. (C), (G) Proteins in fraction NaCl-2 obtained by elution with $100 \mathrm{mM} \mathrm{NaCl}$. (D), (F) Proteins in fraction $\mathrm{NaCl}-3$ obtained by elution with $1 \mathrm{M} \mathrm{NaCl}$. Images $\mathbf{A}, \mathbf{B}, \mathbf{C}$ and $\mathbf{D}$ are for UTUC patients. Images $\mathbf{E}, \mathbf{F}, \mathbf{G}$ and $\mathbf{H}$ for healthy people. 


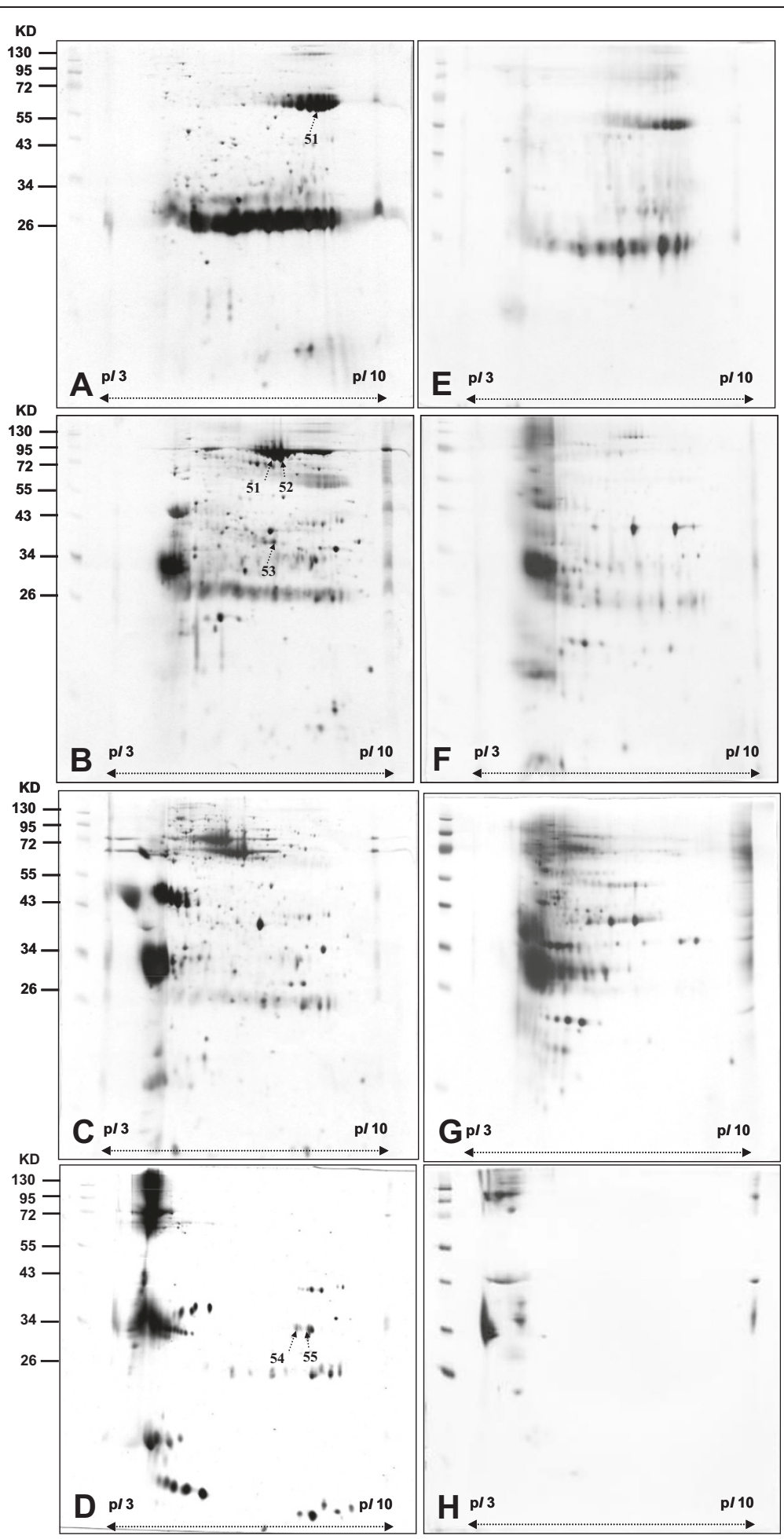

Figure 3 2-DE maps of fractions of urine proteome of UTUC patients and healthy people with obtained by non-fixed volume stepwise elution DEAE-Sephacel anion exchange chromatography. (p/ 3-10 NL) (A), (E) unbound Proteins in fraction (B), (F) Proteins in fraction NaCl-1 obtained by elution with $50 \mathrm{mM} \mathrm{NaCl}$. (C), (G) Proteins in fraction NaCl-2 obtained by elution with $100 \mathrm{mM} \mathrm{NaCl}$. (D), (F) Proteins in fraction $\mathrm{NaCl}-3$ obtained by elution with $1 \mathrm{M} \mathrm{NaCl}$. Images $\mathbf{A}, \mathbf{B}, \mathbf{C}$ and $\mathbf{D}$ are for UTUC patients. Images $\mathbf{E}, \mathbf{F}, \mathbf{G}$ and $\mathbf{H}$ for healthy people. 
Table 2 Summary of differential protein spots of urine between patients with UTUC and healthy people identified by LC-MS/MS

\begin{tabular}{|c|c|c|c|c|c|c|}
\hline Spot no & Protein name & $\begin{array}{c}\text { Accession } \\
\text { no }\end{array}$ & $\begin{array}{c}\text { Calculate } \\
\mathrm{Mw} / \mathrm{pl}\end{array}$ & $\begin{array}{c}\text { Peptide } \\
\text { matched }\end{array}$ & $\begin{array}{l}\text { Sequence } \\
\text { covered\% }\end{array}$ & $\begin{array}{c}\text { MASCOT } \\
\text { score }\end{array}$ \\
\hline 1 & ATP-binding cassette sub-family A member 9 & Q8IUA7 & $184.2 / 6.49$ & 10 & 1 & 38 \\
\hline 2 & sorting nexin-14 & Q9Y5W7 & $102.8 / 6.4$ & 17 & 3 & 34 \\
\hline 3 & serum albumin precursor & P02768 & $69.3 / 5.92$ & 1 & 2 & 57 \\
\hline 4 & F-box/WD repeat protein $1 \mathrm{~A}$ & Q9Y297 & $68.8 / 8.3$ & 29 & 3 & 33 \\
\hline 5 & spermatogenesis-associated protein 7 & Q9P0W8 & $67.6 / 5.9$ & 3 & 4 & 34 \\
\hline 6 & actin & P62736 & $41.9 / 5.23$ & 2 & 9 & 45 \\
\hline 7 & cytokeratin 1 & P04264 & $65.9 / 8.16$ & 3 & 3 & 40 \\
\hline 8 & DNA replication licensing factor MCM2 & P49736 & $101.8 / 5.34$ & 40 & 1 & 50 \\
\hline 9 & proline-serine-threonine phosphatase-interacting protein 1 & O43586 & $47.5 / 5.53$ & 6 & 4 & 40 \\
\hline 10 & $\mathrm{X}$ box-binding protein 1 & P17861 & 28.6/9.71 & 18 & 3 & 35 \\
\hline 11 & immunoglobulin kappa chain $C$ region & P01834 & $11.6 / 5.58$ & 16 & 49 & 151 \\
\hline 12 & immunoglobulin kappa chain V-I region AG & P01593 & $11.9 / 5.67$ & 4 & 31 & 176 \\
\hline 13 & hemopexin precursor & P02790 & $51.6 / 6.55$ & 4 & 7 & 86 \\
\hline 14 & prostaglandin-H2 D-isomerase precursor & P41222 & 21.0/7.66 & 3 & 12 & 33 \\
\hline 15 & immunoglobulin kappa chain $\mathrm{C}$ region & P01834 & $11.6 / 5.58$ & 22 & 49 & 217 \\
\hline 16 & gelsolin precursor & P06396 & $85.6 / 5.9$ & 9 & 7 & 208 \\
\hline 17 & SH3-containing GRB2-like protein 3 & Q99963 & $39.2 / 5.27$ & 16 & 8 & 32 \\
\hline 18 & hemoglobin subunit beta & P68871 & $15.9 / 6.75$ & 9 & 32 & 214 \\
\hline 19 & inter-alpha-trypsin inhibitor heavy chain $\mathrm{H} 4$ & Q14624 & $103.2 / 6.51$ & 13 & 10 & 243 \\
\hline 20 & cytokeratin 10 & P13645 & $59.4 / 5.13$ & 2 & 4 & 38 \\
\hline 21 & basement membrane-specific heparan sulfate proteoglycan core protein precursor & P98120 & $468.8 / 6.06$ & 116 & 4 & 2114 \\
\hline 22 & retinol Binding Protein 4 & P02753 & $22.9 / 5.76$ & 45 & 35 & 233 \\
\hline 23 & Zn-alpha2-glycoprotein & P25311 & $34.7 / 5.71$ & 14 & 45 & 378 \\
\hline 24 & Zn-alpha2-glycoprotein & P25311 & $34.7 / 5.71$ & 5 & 16 & 98 \\
\hline 25 & fibrinogen gamma chain precursor & P02679 & $51.4 / 5.37$ & 19 & 24 & 201 \\
\hline 26 & fibrinogen gamma chain precursor & P02679 & $51.4 / 5.37$ & 5 & 11 & 38 \\
\hline 27 & serotransferrin precursor & P02787 & $77.0 / 6.81$ & 7 & 5 & 48 \\
\hline 28 & serotransferrin precursor & P02787 & $77.0 / 6.81$ & 18 & 13 & 88 \\
\hline 29 & annexin $\mathrm{A} 3$ & P12429 & $36.3 / 5.63$ & 3 & 4 & 37 \\
\hline 30 & dermcidin precursor & P81605 & $11.2 / 6.08$ & 2 & 16 & 48 \\
\hline 31 & calreticulin & P27797 & $48.1 / 4.29$ & 19 & 36 & 493 \\
\hline 32 & haptoglobin & P00738 & $45.1 / 6.13$ & 39 & 13 & 432 \\
\hline 33 & haptoglobin & P00738 & $45.1 / 6.13$ & 41 & 20 & 466 \\
\hline 34 & haptoglobin & P00738 & $45.1 / 6.13$ & 49 & 17 & 668 \\
\hline 35 & haptoglobin & P00738 & $45.1 / 6.13$ & 19 & 15 & 271 \\
\hline 36 & haptoglobin & P00738 & $45.1 / 6.13$ & 5 & 13 & 77 \\
\hline 37 & glial fibrillary acidic protein & P14136 & $49.8 / 5.42$ & 2 & 4 & 43 \\
\hline 38 & alpha-1-microglobulin/bikunin precursor & P02760 & $38.9 / 5.95$ & 41 & 14 & 698 \\
\hline 39 & alpha-1-microglobulin/bikunin precursor & P02760 & $38.9 / 5.95$ & 48 & 15 & 732 \\
\hline
\end{tabular}


Table 2 Summary of differential protein spots of urine between patients with UTUC and healthy people identified by LC-MS/MS (Continued)

\begin{tabular}{|c|c|c|c|c|c|c|}
\hline Spot no & Protein name & $\begin{array}{c}\text { Accession } \\
\text { no }\end{array}$ & $\begin{array}{c}\text { Calculate } \\
\mathrm{Mw} / \mathrm{pl}\end{array}$ & $\begin{array}{l}\text { Peptide } \\
\text { matched }\end{array}$ & $\begin{array}{l}\text { Sequence } \\
\text { covered\% }\end{array}$ & $\begin{array}{c}\text { MASCOT } \\
\text { score }\end{array}$ \\
\hline 40 & alpha-1-microglobulin/bikunin precursor & P02760 & $38.9 / 5.95$ & 45 & 23 & 667 \\
\hline 41 & syntaxin-binding protein 4 & Q6ZWJ1 & $61.7 / 5.16$ & 4 & 7 & 40 \\
\hline 42 & mRNA cap guanine-N7 methyltransferase & O43148 & $54.8 / 6.3$ & 11 & 3 & 52 \\
\hline 43 & transthyretin precursor & P02766 & $15.8 / 5.52$ & 13 & 48 & 217 \\
\hline 44 & transthyretin precursor & P02766 & $15.8 / 5.52$ & 8 & 40 & 142 \\
\hline 45 & alpha-1-microglobulin/bikunin precursor & P02760 & $38.9 / 5.95$ & 5 & 11 & 63 \\
\hline 46 & alpha-1-microglobulin/bikunin precursor & P02760 & $38.9 / 5.95$ & 13 & 11 & 198 \\
\hline 47 & transthyretin precursor & P02766 & $15.8 / 5.52$ & 4 & 14 & 46 \\
\hline 48 & serine/threonine-protein kinase MRCK beta & Q9Y5S2 & $194.1 / 5.91$ & 3 & 2 & 56 \\
\hline 49 & serum albumin precursor & P02768 & $69.3 / 5.92$ & 51 & 25 & 594 \\
\hline 50 & serotransferrin precursor & P02787 & $77.0 / 6.81$ & 42 & 21 & 441 \\
\hline 51 & serum albumin precursor & P02768 & $69.3 / 5.92$ & 92 & 26 & 1359 \\
\hline 52 & serum albumin precursor & P02768 & $69.3 / 5.92$ & 48 & 26 & 662 \\
\hline 53 & annexin A2 & P07355 & $38.58 / 7.57$ & 28 & 37 & 505 \\
\hline 54 & Ig gamma- 1 chain $C$ region & P01857 & $36.0 / 8.46$ & 20 & 26 & 190 \\
\hline 55 & Ig gamma-1 chain $C$ region & P01857 & $36.0 / 8.46$ & 12 & 25 & 104 \\
\hline
\end{tabular}

patients with UTUC in comparison with those of healthy people.

CALR, an endoplasmic reticulum (ER) chaperone, plays the role as a stress protein. The over-expression of CALR occurs in several malignancies, such as breast, prostate, liver, bladder, and lung cancers [15-18]. It has been reported that the expressions of CALR in both tumor tissue and urine of patients with bladder cancer were higher than in those of healthy people $[19,20]$. Elevated CALR expression was showed by 2-DE, western blot analysis, and immunohistochemistry in the urine and tissues of patients with bladder cancer [19]. Enzymelinked immunosorbent assay was used for testing CALR with a sensitivity of $67.9 \%$ and a specificity of $80 \%$ for the detection of bladder cancer [20]. Our study for the first time showed the over-expression of CALR in the urine

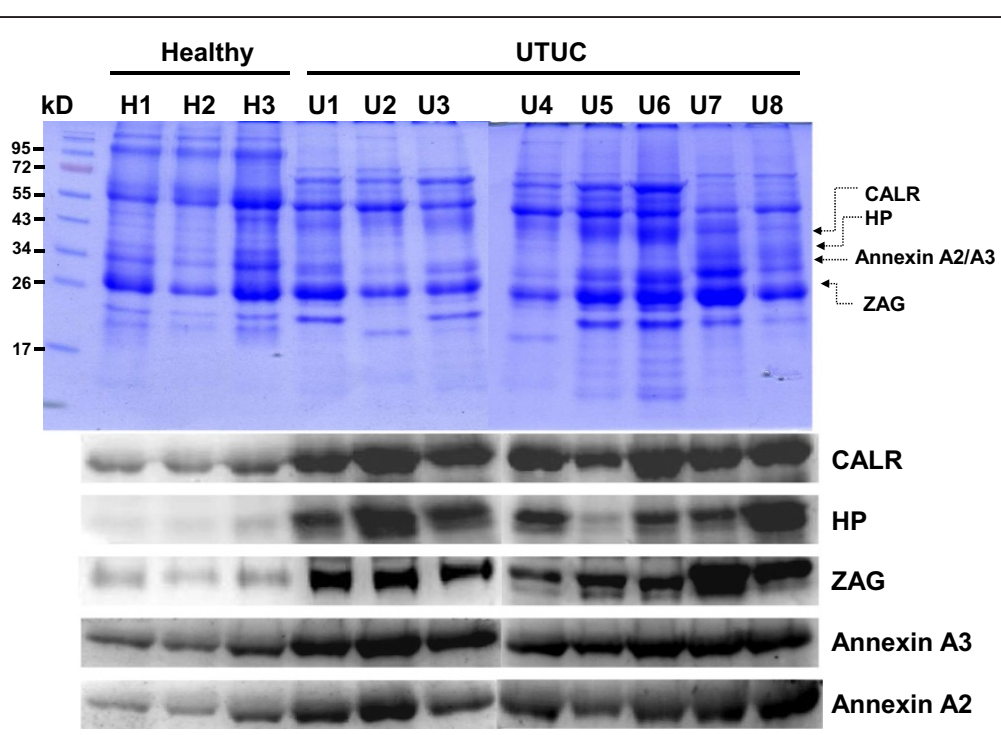

Figure 4 Comparison of CBR staining of western blot analysis of zinc-alpha-2-glycoprotein (ZAG), Calreticulin (CALR), Annexin A2, Annexin $A 3$ and hapatoglobin $(\mathrm{Hp})$ in urine of healthy people and urine of UTUC patients, each with a loading of $20 \mu \mathrm{g}$ urine protein. Lane $\mathrm{H} 1-\mathrm{H} 3$ for individual urine of three healthy people and Lane U1-U5 for individual urine of five UTUC patients. 


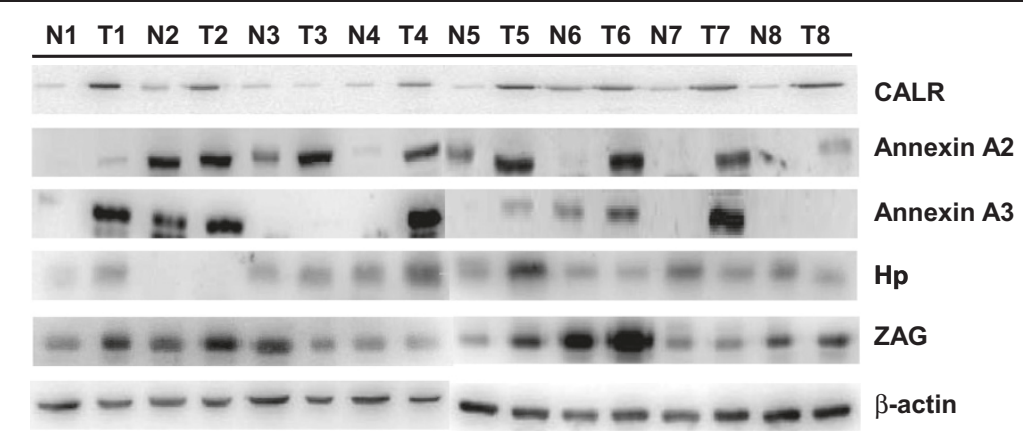

Figure 5 Side-by-side comparison using western blot analysis of zinc-alpha-2-glycoprotein (ZAG), Calreticulin (CALR), annexin A2, annexin $\mathrm{A} 3$ and hapatoglobin $(\mathrm{Hp})$ of tumor tissues and normal tissuess, each well with a loading of $\mathbf{2 0} \boldsymbol{\mu g}$ protein. Tumor tissue was presented by $\mathrm{T}$ and normal tissue was presented by $\mathrm{N}$.

of patients with UTUC. Similar over-expression was also found in and the tumor tissues of patients with UTUC in comparison with healthy controls. Furthermore, in the current study this ER chaperone protein was over-expressed in the tumor areas of seven tumor/adjacent normal tissue pairs (87.5\%). These data suggested that CALR is a protein secreted from UTUC tumor tissues and it is potentially a marker for UTUC.

Annexin A2 is calcium-dependent phospholipidbinding protein. It is involved in several biological processes such as immune responses, anti-inflammatory effects, $\mathrm{Ca}^{2+}$ transport, $\mathrm{Ca}^{2+}$-dependent exocytosis, and phospholipase A2 regulation. It also plays roles in the regulation of cellular growth and signal transduction pathways. Annexin A2, a potential serum marker for hepatocellular carcinoma may play an important role in liver cancer progression [21]. Down-regulation of annexin A2 in hepatocellular carcinoma cells reduced the secretion of MMP, migration ability, and invasive potential and also affected the cytoskeleton rearrangement of tumor cells [22]. Annexin A2 protein may play an important role in carcinogenesis of oral squamous cell carcinoma (OSCC). It may also serve as a potential biomarker for different pathological grade of this tumor [23]. This study is the first report on the presence of annexin A2 in the urines of patients with UTUC. The expression of annexin A2 in the tumor tissue of a patient with UTUC was higher than in the normal tissue of the same patient by western blotting analysis and immunohistochemistry and the over-expression was also found in the tumor areas of eleven tumor/adjacent normal tissue pairs $(84.6 \%)$. These data in our study

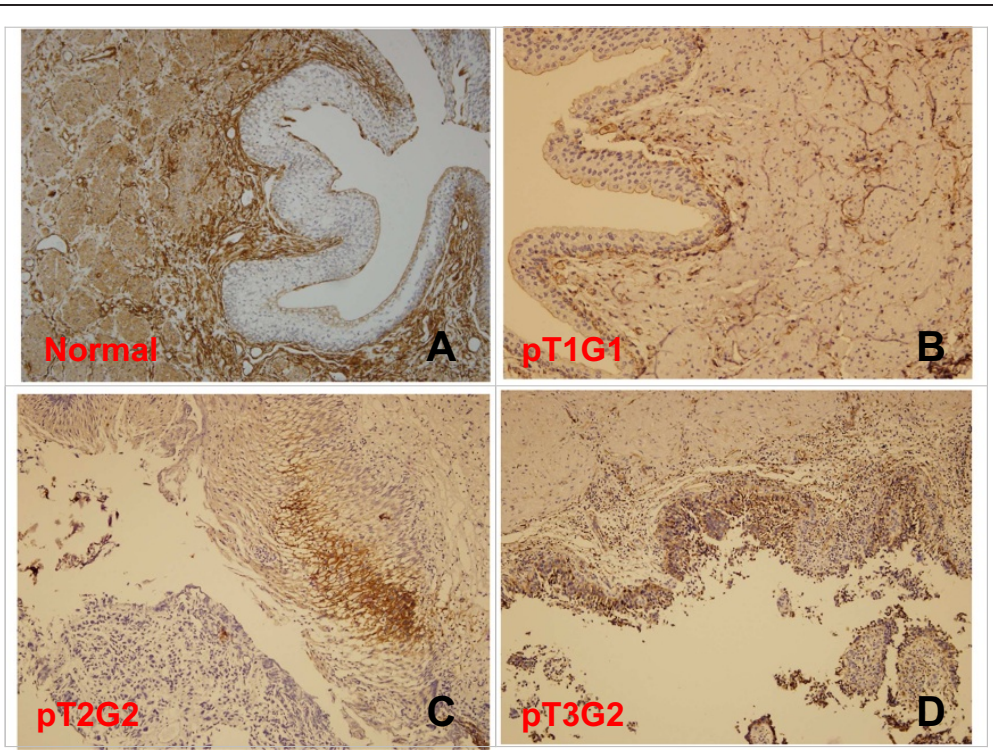

Figure 6 Immunoreactivity staining of annexin A2 expression from patients, using immunohitochemistry (IHC). (A) normal urothelium, positive in stroma, negative in urothelium. (B) pT1G1, negative in urothelial carcinoma. (C) pT2G2, positive in urothelial carcinoma (D) pT3G2, positive in urothelial carcinoma. Magnification: $(\mathbf{A}, \mathbf{B}, \mathbf{C}, \mathbf{D}) \times 100$. 
Table 3 The results of immunohistochemistry of annexin A2 expression in UTUC and normal tissues by patient (+: positive expression, -: no negative expression)

\begin{tabular}{ccccc}
\hline ID & T stage & Tumor grade & UTUC & Control \\
\hline 1 & T1 & G1 & - & - \\
2 & T2 & G2 & + & - \\
3 & T2 & G1 & + & - \\
4 & T1 & G1 & + & - \\
5 & T3 & G3 & + & - \\
6 & T2 & G1 & + & - \\
7 & T3 & G3 & + & - \\
8 & T2 & G1 & + & - \\
9 & T3 & G3 & + & + \\
10 & T3 & G2 & + & - \\
11 & T1 & G1 & - & - \\
12 & T1 & G1 & + & - \\
13 & T3 & G2 & + & - \\
\hline
\end{tabular}

strongly support that annexin A2 is a crucial marker for UTUC.

Annexin A3 belongs to a family of phospholipid and calcium binding proteins. It has been implicated in cell migration and differentiation, immunomodulation, bone formation and mineralization [24]. Annexin A3 also play roles in cancer dependent autoimmne regulation against angiogenesis [25], exosomes/prosteasomes [26,27], and calcium dependent processes. Recently studies indicated annexin A3 is an inversely correlated marker for colorectal cancer [28], ovarian cancer [29], and prostate cancer [30]. It has been shown that annexin A3 in urine with a highly specific noninvasive marker for prostate cancer early detection $[27,31]$. Similar to annexin A2, we for the first time showed that the over-expression of annexin A3 in the urine and tumor tissues of patients with UTUC in comparison with healthy controls while annexin A3 was over-expressed in the tumor areas of eight tumor/adjacent normal tissue pairs (61.5\%). Even

Table 4 Summary of annexin A2 expression in UTUCs and controls

\begin{tabular}{lccccc}
\hline Annexin A2 & \multicolumn{2}{c}{ UTUC } & & \multicolumn{2}{c}{ Control } \\
\cline { 2 - 3 } Expression & Positive & Negative & & Positive & Negative \\
\hline T Stage & & & & \\
T1 $(\mathrm{N}=4)$ & $2(50 \%)$ & $2(50 \%)$ & & $0(0 \%)$ & $4(100 \%)$ \\
T2 $(\mathrm{N}=4)$ & $4(100 \%)$ & $0(0 \%)$ & & $0(0 \%)$ & $4(100 \%)$ \\
T3 $(\mathrm{N}=5)$ & $5(100 \%)$ & $0(0 \%)$ & & $1(20.0 \%)$ & $4(80.0 \%)$ \\
Grading & & & & \\
$1(\mathrm{~N}=7)$ & $5(71.4 \%)$ & $2(28.6 \%)$ & & $0(0 \%)$ & $7(100 \%)$ \\
$2(\mathrm{~N}=3)$ & $3(100 \%)$ & $0(0 \%)$ & & $0(0 \%)$ & $3(100 \%)$ \\
$3(\mathrm{~N}=3)$ & $3(100 \%)$ & $0(0 \%)$ & & $1(33.3 \%)$ & $2(66.7 \%)$ \\
\hline
\end{tabular}

though two UTUC tumor tissues and most normal tissues did not express annexin A3, both annexin A2 and annexin A3 showed stronger expression in UTUC urine samples than those in the urine of healthy control. This demonstrates that high-level expression of annexin A2/ A3 in human urine samples still highlights their biomedical and diagnostic value for UTUC.

ZAG is a special protein. It stimulates lipid degeneration in adipocytes [32] and appears over-expressed in certain tumors and has been often recognized as a possible cancer marker [33-35]. It has been reported that ZAG initially appeared in urinary tract luminal surface. During the progression of the tumor, it transformed to the basal location. The highest level of ZAG among invasive bladder cancer sites was at the stage pT2-3 [33]. $\mathrm{Hp}$ promotes the accumulation of hydroxyl radicals which causes oxidative tissue damages [36]. Hp exists in two allelic forms in human body, denoted as $\mathrm{Hp} 1$ and $\mathrm{Hp} 2$. Elevated expression of $\mathrm{Hp} 2$ was reported in the plasma of patients with pancreatic, cervical, and breast cancer [36-38]. The results of this study demonstrated that ZAG and Hp had a stronger intensity in the urines of UTUC patients than in those of healthy people. However, higher expression of ZAG and $\mathrm{Hp}$ was not found in the western blot data of tumor tissues. We propose that the over-expression of ZAG and $\mathrm{Hp}$ in the urine of UTUC patients compared with that in healthy people, even though not consistent with the data in tumor tissues, it still somewhat reflects the possibilities of diseases or tumors in the urinary tract.

\section{Conclusions}

Comparative proteomic analysis was conducted to investigate potential tumor markers for UTUC. A non-fixed volume stepwise elution anion exchange chromatography using DEAE-Sephacel as gel resin was employed to fractionate the total urine into four fractions prior to performing 2-DE. The 2-DE map of the urine of patients with UTUC showed a total of 1,028 proteins spots. Among them, fifty-five differential spots were identified. Three proteins, CALR, annexin A2 and annexin A3 presented with over-expression in both the urine and tissues of UTUC patients in comparison with that in the healthy and normal counterparts. The data on the urine and tumor tissues obtained from UTUC patients which were discovered and verified by proteomic and immunological analysis strongly suggested that CALR, annexin A2 and annexin A3 are essential proteins secreted from UTUC tumor tissues. Our study also established the biomedical linkage of the critical over-expression of CALR, annexin A2 and annexin A3 between the urine and tumor tissues of UTUC patients. CALR, annexin A2 and annexin $\mathrm{A} 3$ are very likely a panel of crucial markers in UTUC patients. 


\section{Abbreviations}

2-DE: Two dimensional gel electrophoresis; CALR: Calreticulin; Hp: Haptoglobin; UTUC: Upper tract urothelial carcinoma; WAX: Weak anion exchange; ZAG: Zinc-alpha-2-glycoprotein.

\section{Competing interests}

The authors declare that they have no competing interests.

\section{Authors' contributions}

$\mathrm{CL}$ carried out the proteomic study, participated in the design of the study, the collection of urine and tissues, performed the 2-DE and the western blot analysis, and drafted the manuscript. JL carried out the 2-DE, western blot analysis, and immunoreactivity. $\mathrm{HH}$ participated in the 2-DE. YK, JH, and JC participated in the design of the study. ID participated in the design of the study and drafted the manuscript. YW conceived of the study, and participated in its design and conordination, and drafted the manuscript. All authors read and approved the final manuscript.

\section{Acknowledgment}

This study was supported in part by grants from National Science Council of Taiwan (NSC 98-2313-B-276-001-MY3 and NSC 101-2313-B-276-002) and the Research Fund of Buddhist Dalin Tzu Chi General Hospital (Project No. DTCRD 96(2)-14). We are grateful to Applied Biotechnology Medicine cooperation (Pingtung, Taiwan) for LC-MS/MS analysis.

\section{Author details}

'Department of Urology, Dalin Tzu Chi Hospital, Buddhist Tzu Chi Medical Foundation, Chiayi, Taiwan. ${ }^{2}$ Graduate Institute of Veterinary Medicine, National Pingtung University of Science and Technology, Pingtung, Taiwan. ${ }^{3}$ Department of Beauty Science, Meiho University, Pingtung, Taiwan. ${ }^{4}$ Institute of Medicine, China Medical University, Taichung, Taiwan. ${ }^{5}$ Graduate Institute of Biotechnology, National Pingtung University of Science and Technology, Pingtung, Taiwan. ${ }^{6}$ Department of Food Science and Nutrition, Meiho University, Pingtung, Taiwan. ${ }^{7}$ Graduate Institute of Applied Healthy and Biotechnology, Meiho University, Pingtung, Taiwan.

\section{Received: 2 December 2013 Accepted: 20 May 2014}

Published: 23 May 2014

\section{References}

1. Li WM, Li CC, Ke HL, Wu WJ, Huang CN, Huang CH: The prognostic predictors of primary ureteral transitional cell carcinoma after radical nephroureterectomy. J Urol 2009, 182:451-458.

2. Oldbring J, Glifberg I, Mikulowski P, Hellsten S: Carcinoma of the renal pelvis and ureter following bladder carcinoma: frequency, risk factors and clinicopathological findings. J Urol 1989, 141:1311-1313.

3. Busby JE, Brown GA, Tamboli P, Kamat AM, Dinney CP, Grossman HB, Matin SF: Upper urinary tract tumors with nontransitional histology: a single-center experience. Urology 2006, 67:518-523.

4. Kikuchi E, Horiguchi Y, Nakashima J, Hatakeyama N, Matsumoto M, Nishiyama T, Murai M: Lymphovascular invasion independently predicts increased disease specific survival in patients with transitional cell carcinoma of the upper urinary tract. J Urol 2005, 174:2120-2123.

5. Marshall T, Williams KM: Clinical analysis of human urinary proteins using high resolution electrophoretic methods. Electrophoresis 1998 19:1752-1770

6. Lu CM, Wu YJ, Chen CC, Hsu JL, Chen JC, Chen JY, Huang CH, Ko YC: Identification of low-abundance proteins via fractionation of the urine proteome with weak anion exchange chromatography. Proteome Sci 2011, 9:17.

7. Kiernan U, Tubbs K, Nedelkov D, Niederkofler E, McConnell E, Nelson R: Comparative urine protein phenotyping using mass spectrometric immunoassay. J Proteome Res 2003, 2:191-197.

8. Liu Cl, Wang YL, Lin JJ, Su JH, Chiu CC, Chen JC, Chen YF, Wu YJ: Proteomic profiling of the 11-dehydrosinulariolide-treated oral carcinoma cells Ca9-22: effects on the cell apoptosis through mitochondrial-related and ER stress pathway. J Proteomics 2012, 75:5578-5589.

9. Li HH, Su JH, Chiu CC, Lin JJ, Yang ZY, Hwang WI, Chen YK, Lo YH, Wu YJ: Proteomic investigation of the sinulariolide-treated melanoma cells A375: effects on the cell apoptosis through mitochondrial-relate pathway and activation of caspase cascade. Mar Drugs 2013, 11:2625-2642.
10. Rydén M, Agustsson T, Andersson J, Bolinder J, Toft E, Arner P: Adipose zinc-a2-glycoprotein is a catabolic marker in cancer and noncancerous states. J Intern Med 2012, 271:414-420.

11. Hisaoka M, Matsuyama A, Nakamoto M: Aberrant calreticulin expression is involved in the dedifferentiation of dedifferentiated liposarcoma. Am J Pathol 2012, 180:2076-2083.

12. Zhang X, Liu S, Guo C, Zong J, Sun MZ: The association of annexin A2 and cancers. Clin Transl Oncol 2012, 14:634-640.

13. Wu N, Liu S, Guo C, Hou Z, Sun MZ: The role of annexin A3 playing in cancers. Clin Transl Oncol 2012. pub ahead of print.

14. Carlsson MC, Cederfur C, Schaar V, Balog Cl, Lepur A, Touret F, Salomonsson E, Deelder AM, Fernö M, Olsson H, Wuhrer M, Leffler H: Calectin-1-binding glycoforms of haptoglobin with altered intracellular trafficking, and increase in metastatic breast cancer patients. PLoS One 2011, 6:e26560.

15. Alur M, Nguyen MM, Eggener SE, Jiang F, Dadras SS, Stern J, Kimm S, Roeh K, Kozlowski J, Pins M, Michalak M, Dhir R, Wang Z: Suppressive roles of calreticulin in prostate cancer growth and metastasis. Am J Pathol 2009, 175:882-890.

16. Chignard N, Shang S, Wang H, Marrero J, Brechot C, Hanash S, Beretta L: Cleavage of endoplasmic reticulum proteins in hepatocellular carcinoma: detection of generated fragments in patient sera. Gastroenterology 2006, 130:2010-2022.

17. Gromov P, Gromova I, Bunkenborg J, Cabezon T, Moreira JM, TimmermansWielenga V, Roepstorff P, Rank F, Celis JE: Up-regulated proteins in the fluid bathing the tumour cell microenvironment as potential serological markers for early detection of cancer of the breast. Mol Oncol 2010, 4:65-89.

18. Iwaki H, Kageyama S, Isono T, Wakabayashi Y, Okada Y, Yoshimura K, Terai A Arai $Y$, Iwamura H, Kawakita M, Yoshiki T: Diagnostic potential in bladder cancer of a panel of tumor markers (calreticulin, gamma -synuclein, and catechol-o-methyltransferase) identified by proteomic analysis. Cancer Sci 2004, 95:955-961.

19. Kageyama S, Isono T, Iwaki H, Wakabayashi Y, Okada Y, Kontani K, Yoshimura K, Terai A, Arai Y, Yoshiki T: Identification by proteomic analysis of calreticulin as a marker for bladder cancer and evaluation of the diagnostic accuracy of its detection in urine. Clin Chem 2004, 50:857-866.

20. Kageyama S, Isono T, Matsuda S, Ushio Y, Satomura S, Terai A, Arai Y, Kawakita M, Okada K, Yoshiki T: Urinary calreticulin in the diagnosis of bladder urothelial carcinoma. Int J Urol 2009, 16:481-486.

21. Ji NY, Park MY, Kang YH, Lee Cl, Kim DG, Yeom Yl, Jang YJ, Myung PK, Kim JW, Lee HG, Kim JW, Lee K, Song EY: Evaluation of annexin II as a potential serum marker for hepatocellular carcinoma using a developed sandwich ELISA method. Int J Mol Med 2009, 24:765-771.

22. Zhao P, Zhang W, Tang J, Ma XK, Dai JY, Li Y, Jiang JL, Zhang SH, Chen ZN: Annexin II promotes invasion and migration of human hepatocellular carcinoma cells in vitro via its interaction with HAb18G/CD147. Cancer Sci 2010, 101:387-395

23. Zhong LP, Wei KJ, Yang X, Zhang L, Zhou XJ, Pan HY, Li J, Chen WT, Zhang $Z Y$ : Increased expression of Annexin A2 in oral squamous cell carcinoma. Arch Oral Biol 2009, 54:17-25.

24. Gerke V, Creutz CE, Moss SE: Annexins: linking Ca2+ signalling to membrane dynamics. Nat Rev Mol Cell Biol 2005, 6:449-461.

25. Park JE, Lee DH, Lee JA, Park SG, Kim NS, Park BC, Cho S: Annexin A3 is a potential angiogenic mediator. Biochem Biophys Res Commun 2005, 337:1283-1287.

26. Minelli A, Ronquist G, Carlsson L, Mearini E, Nilsson O, Larsson A Antiprostasome antibody titres in benign and malignant prostate disease. Anticancer Res 2005, 25:4399-4402.

27. Schostak M, Schwall GP, Poznanovic S, Groebe K, Muller M, Messinger D, Miller K, Krause H, Pelzer A, Horninger W, Klocker H, Hennenlotter J, Feyerabend S, Stenzl A, Schrattenholz A: Annexin A3 in urine: a highly specific noninvasive marker for prostate cancer early detection. J Urol 2009, 181:343-353.

28. Madoz-Gúrpide J, López-Serra P, Martínez-Torrecuadrada JL, Sánchez L, Lombardía L, Casal Jl: Proteomics-based validation of genomic data: applications in colorectal cancer diagnosis. Mol Cell Proteomics 2006, 5:1471-1483.

29. Yin J, Yan X, Yao X, Zhang Y, Shan Y, Mao N, Yang Y, Pan L: Secretion of annexin $A 3$ from ovarian cancer cells and its association with platinum resistance in ovarian cancer patients. J Cell Mol Med 2012, 16:337-348.

30. Roobol MJ, Haese A, Bjartell A: Tumour markers in prostate cancer III: biomarkers in urine. Acta Oncol 2011, 1:85-89. 
31. Jamaspishvili T, Kral M, Khomeriki I, Student V, Kolar Z, Bouchal J: Urine markers in monitoring for prostate cancer. Prostate Cancer Prostatic Dis 2010, 13:12-19.

32. Bing C, Bao Y, Jenkins J, Sanders P, Manieri M, Cinti S, Tisdale MJ, Trayhurn $P$ : Zinc-alpha2-glycoprotein, a lipid mobilizing factor, is expressed in adipocytes and is up-regulated in mice with cancer cachexia. Proc Natl Acad Sci U S A 2004, 101:2500-2505.

33. Irmak S, Tilki D, Heukeshoven J, Oliveira-Ferrer $L$, Friedrich $M$, Huland $H$, Ergun S: Stage-dependent increase of orosomucoid and zinc-alpha2glycoprotein in urinary bladder cancer. Proteomics 2005, 5:4296-4304.

34. Hale L, Price D, Sanchez L, Demark-Wahnefried W, Madden J: Zinc alpha-2glycoprotein is expressed by malignant prostatic epithelium and may serve as a potential serum marker for prostate cancer. Clin Cancer Res 2001, 7:846-853.

35. Skipworth R, Stewart G, Bhana M, Christie J, Sturgeon C, Guttridge D, Cronshaw A, Fearon K, Ross J: Mass spectrometric detection of candidate protein biomarkers of cancer cachexia in human urine. Int J Oncol 2010, 36:973-982.

36. Carter K, Worwood M: Haptoglobin: a review of the major allele frequencies worldwide and their association with diseases. Int $\mathrm{L}$ Lab Hematol 2007, 29:92-110.

37. Awadallah SM, Atoum MF: Haptoglobin polymorphism in breast cancer patients form Jordan. Clin Chim Acta 2004, 341:17-21.

38. Deng R, Lu Z, Chen Y, Zhou L, Lu X: Plasma proteomic analysis of pancreatic cancer by 2-dimensional gel electrophoresis. Pancreas 2007, 34:310-317.

doi:10.1186/1471-2407-14-363

Cite this article as: Lu et al: A panel of tumor markers, calreticulin, annexin $A 2$, and annexin $A 3$ in upper tract urothelial carcinoma identified by proteomic and immunological analysis. BMC Cancer 2014 14:363.

\section{Submit your next manuscript to BioMed Central and take full advantage of:}

- Convenient online submission

- Thorough peer review

- No space constraints or color figure charges

- Immediate publication on acceptance

- Inclusion in PubMed, CAS, Scopus and Google Scholar

- Research which is freely available for redistribution 